測定せり

1. $\mathrm{Na}_{2} \mathrm{SO}_{4}, \mathrm{MgSO}_{4},\left(\mathrm{NH}_{4}^{*}\right)_{2} \mathrm{SO}_{4}$, 葡萄糖及び此等の混合物を添加せる凝固浴にて紡絲せる絲の吸收度は添

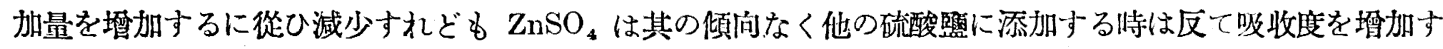

2. 吸收度と凝固速度, 絲の强伸度, 斷面の形狀との間には普遍的なる一定の關係なし

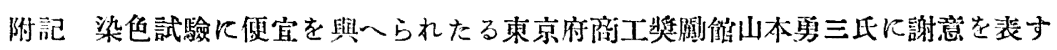

（東京帝國大學工學部軈用化學科研究室）（炤和七年六月一四日受理）

\title{
大豆粕加 水分解物之醬油の比較研究
}

鹿園 直治・友田 冝孝

緒

言

此處に大豆粕加水分解物とは大日本人造肥料株式會社王子工場にて製造せるソヤメントの事なり故に先づソ ヤメントに就て以下簡戰に述べむ一言にして云へばンャメントは䇴油の原料なり刎論それ自身整油の代用にな

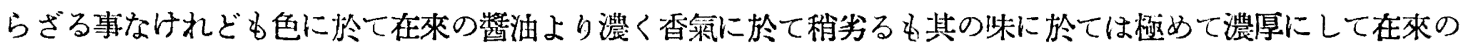

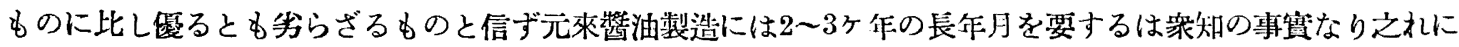
は幾多の原因あらんも醬油の原料たる大豆蛋白の数菌，酵母或は細菌等の微生物の作用に依る縟慢なる分解も 其の主なる原因なるべし此の加水分解をせしむるに微生物に代ふるに學酸を以てし迅速に美味を得んとするの

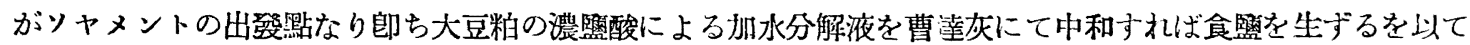

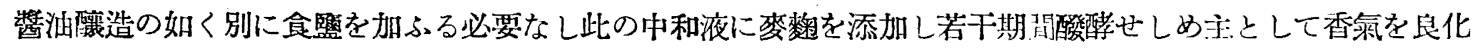

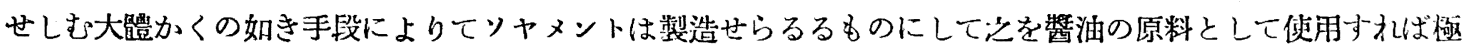
めて短期間に䣽油を得らるるを以て數年前大日本人造肥料會社にて製造せし以來年々盛んにならむと亦る傾向 を有す

著者等は主として此のソヤメント（2號）及び醬油（ヤマサ印）の䇪素分布狀態を比較せり

醬油の突素物に就て

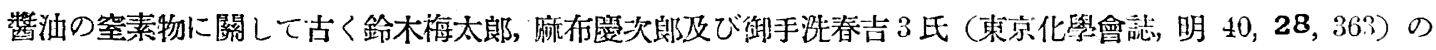

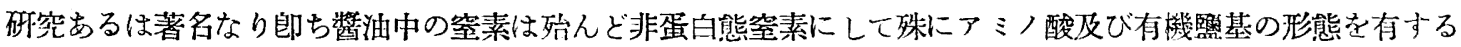

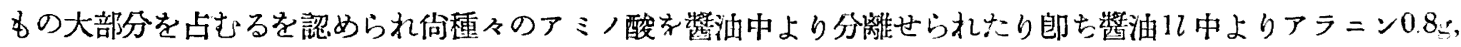

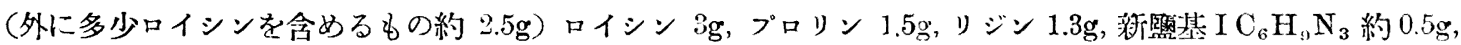

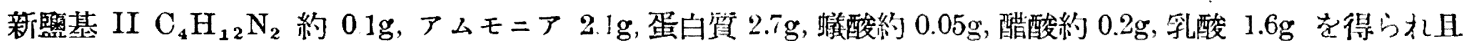
アスパラギン酸, チロシン, シスチン, ポリペプチドの存在を認められたり以上の破究にては其の存在を疑はれ

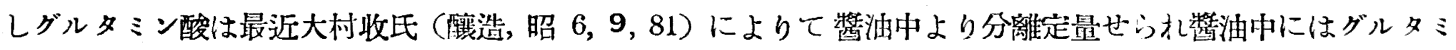

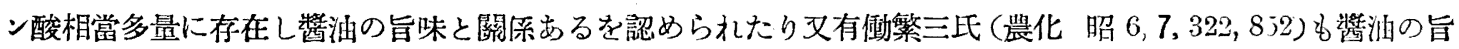

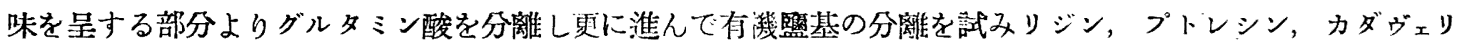

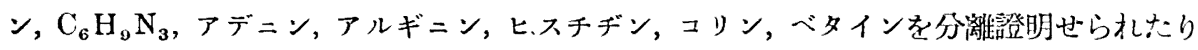

試料物理的及化學的性質

色相 ソヤメント及び醬油共に喑赤褐色を呈する雨者を水にて 5 倍にうすめヅボスク比色計にて見ればン 
ヤメントは約 25 倍濃厚なり

表面張力 $d u$ Noïy 氏の裝置を用ひ $15^{\circ} \mathrm{C}$ に於て測定せるに次の如し

$\begin{array}{cccc} & \text { 水 } & \text { ソャメト } & \text { 敕 油 } \\ \text { 表面張力 dynes } / \mathrm{cm} & \text { it } & 47 & 55\end{array}$

粘度 オストワルド粘度訓にて $20^{\circ} \mathrm{C}$ に於て測定せり

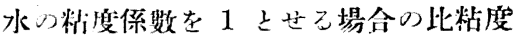

ソヤメント

8.57
慗 油

5.09

ソャメント及びャマサ醬油の近似分析の結果は次の㛎し

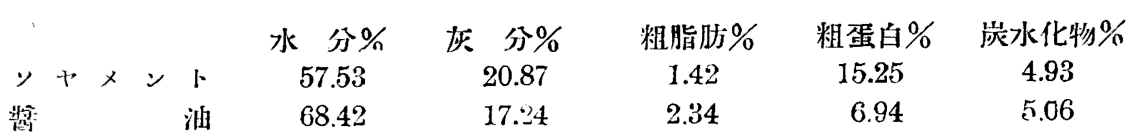

少純蛋白及びアミノ酸窒素を测定せり純蛋白はバルンスタイン氏法のスッツァー氏改良法（アブデルハルデ ン氏 Handbuch der biologischen A beitsmethoden, IV Abt. Teil 9) により アミノ酸室素はヴっンスラ イク氏の方法（主としてアブデルハルデン氏藷書 I Abt. Teil 7 及び增野䔈氏, 東工試 21 包 2 號を參照す)に 從ひ 5 分問振湯 15 分放置の條件にて測定せり蓋しソャメントに就き 5 分振渴盅せる後放置時間を種々に變へ てアミノ酸窒素を測定せるに上上の條件にては略恒數を得るを認めたるが故なり郎ち

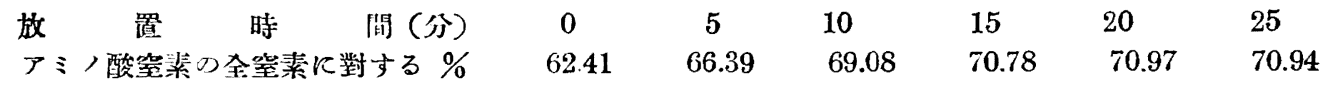

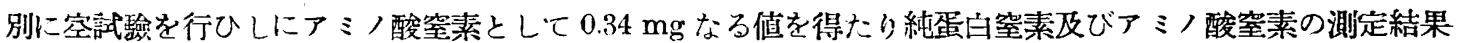
は次の如し合せて全䇪素の量も記す

\begin{tabular}{|c|c|c|c|c|c|}
\hline \multirow[b]{2}{*}{ 全 䇪 素 } & \multirow[b]{2}{*}{$\bullet$} & \multicolumn{2}{|c|}{ 試料 $100 \mathrm{cc}$ 小 } & \multicolumn{2}{|c|}{ 全窒溸 100 分中 } \\
\hline & & $\begin{array}{c}\text { ソャメント } \\
3.055 \mathrm{~g}\end{array}$ & $\begin{array}{c}\text { 篦．油 } \\
1.327 \mathrm{~g}\end{array}$ & $\begin{array}{c}\text { ソャメント } \\
100 \%\end{array}$ & $\begin{array}{l}\text { 鷔 油 } \\
100 \%\end{array}$ \\
\hline 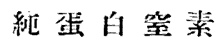 & & 0.019 & 0.017 & 0.63 & 1.24 \\
\hline 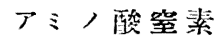 & & 2.157 & 0.720 & 70.78 & 54.1 \\
\hline
\end{tabular}

更に還元糖をアリン氏の方法によりフェーリング液の還元せられたる銅を重量法にて定量せるもンヤメント の場合亞酸化銅の沈港は赤色を呈さずむしろ黄褐色を示したり向試料を硝酸にて酸化しガラッタンをミューシ ン酸として定量せむとせしもミューシン酸の結晶はンヤメント，醬汕共に析出せざりき
還 元 糖 \%
ソヤメント
0.86
怔 油
3.98

次に試料を膀胱に入れ 14 畫夜透析せるに琖留液は共に黑褐色を呈し無味無臭なり郎ち味に關與する物質は 全く残らずされと殘液を加熱寸れば共に醬油樣香氣を放つ蒸氯乾固せる黑色の殘洫及び其の灰分を湘定せるに 次の如し

$\begin{array}{lccc} & & \text { ソャメント } & \text { 酱 } \\ \text { 殘 } & \text { 油 } \\ \text { 灰分 \%(殘留物に對する) } & 0.8 & 1.2 \\ & 15.0 & 8.5\end{array}$

空素分布狀態

ヴァンスライク氏の方法を值接試料に焦用しアブデルハルデン氏著書 I A bt. Teil 7 に從ひ其の窒素分布狀 態を見たり

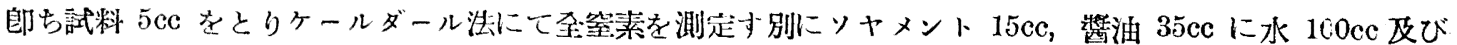


泡立を防ぐ目的にてアルコール 100ec を加へ更に石灰液(水 $100 \mathrm{cc}$ 中に $\mathrm{Ca}(\mathrm{OH})_{2}$ として $10 \mathrm{~g}$ 含む割合)をり ヤメントの場合は $10 \mathrm{cc}$ 醬油の場合には $2 \mathrm{cc}$ 加へ $26 \mathrm{~mm} 45 \sim 46^{\circ} \mathrm{C}$ にて蒸溜し蚠出するアムモニアを涀定濃度 の硫酸に導き常法の如く定量しアムモニア態咥素を求む，此のアムモニア態等素定量の場合石灰液の量を種々

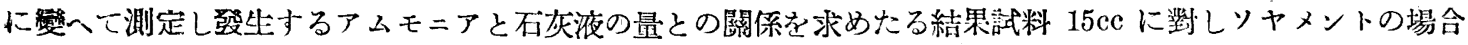
は石灰液 7cc 灃油にては 5cc にてアムモニア量は略恒整を得るを認めたりアムモニアを除去せる线留液を濾

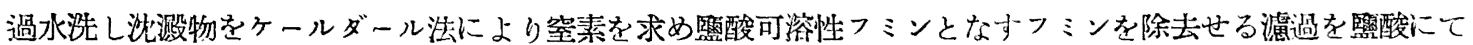

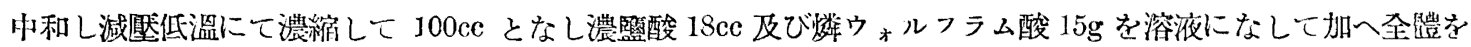

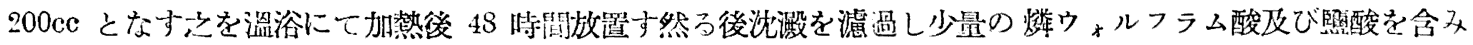

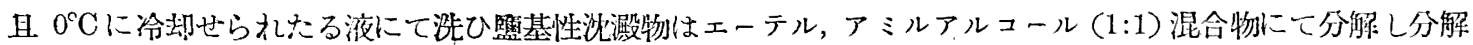

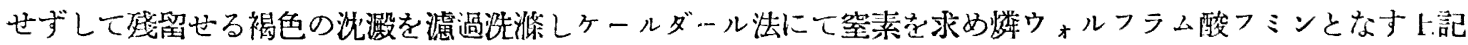

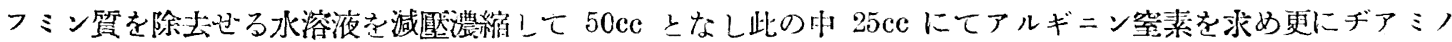

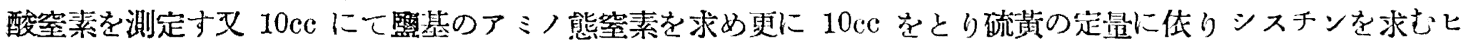
スチデン及びリジン態害素は次式にて計算す

ヒスチヂン洷素 $=3 / 2$ (非アミノ窒素 $-8 / 4$ アルギニン空菜)

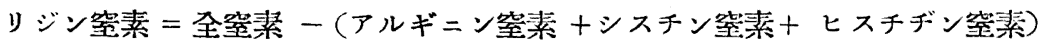

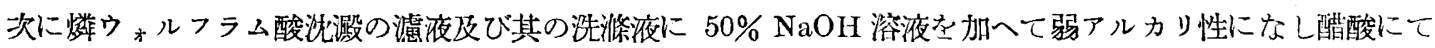

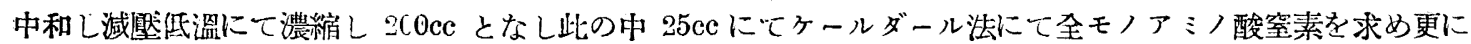
10ccをとりてヴァンスライク氏の裝置によりてアミノ態空素を求め全䇪素及びアミノ態窒素の差を以て非アミ ノ態穻素となす

以上の苗驗にて得たる結果を表示すれい゙次の如し

全㗌素 100 分中

$$
\begin{aligned}
& \text { アムモニア態 } \\
& \text { フ ン 態 }
\end{aligned}
$$

$\{$ 監 酸 可 溶 性 燃ウォルフラム酸 ヂアミノ酸龍

$\begin{array}{cr}\text { ソャメント } & \text { 油 } \\ 9.41 & 9.82 \\ 6.14 & 19.17 \\ 0.52 & 2.63 \\ 5.62 & 16.54 \\ 27.02 & 22.63\end{array}$

婯

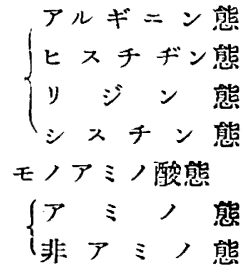

11.10

9.90

5.05

0.96

50.53

43.77

6.81

旨
7.15

13.97

13.77

（1）ソャメント及び醬油を分析せるに窒素量に於て大なる差晎を示せり佾純蛋白に於ては咯同じなるもア ミノ酸にてはンヤメントは約 3 倍多く含有す

（2）ヴァンスライク氏の方法を直接試料に㤫用し其の窒素分布狀態を見たり其の結果よりすればフミン態 に於て大差を示しヂアミノ酸に於ては概してソャメントの多し之等のアルギニン，ヒスチヂン，リジン，シ

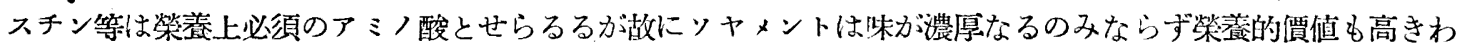
けなり

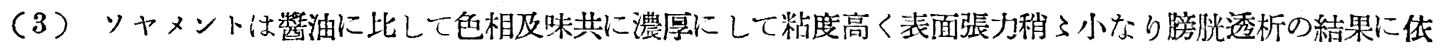
るにソャメントはコロイド物質の含有量少きものの如し

本政究に對して多大なる便宜を與一られたる大日本人造肥料怢式會社，问司務氏，下光太郎氏及兒玉静記氏等 К深厚なる鸲意を表す 